\title{
Building long-term relationships between producers and trader groups in the non-timber forest product sector in Cameroon
}

\author{
Foundjem-Tita D. ${ }^{1,2,3 *}$, Degrande A. ${ }^{3}$, D'Haese M. ${ }^{1}$, Van Damme . $^{2}$, Tchoundjeu $Z^{3}$, Gyau A. ${ }^{3}$, \\ Facheux $\mathrm{C}^{3}$ and Mbosso $\mathrm{C}^{3}$ \\ ${ }^{1}$ Department of Agricultural Economics, Ghent University, Coupure links 653, 9000 Gent, Belgium. \\ ${ }^{2}$ Laboratory for Tropical and Subtropical Agronomy and Ethnobotany, Ghent University, Coupure Links 653, 9000 Gent, \\ Belgium. \\ ${ }^{3}$ World Agroforestry Centre (ICRAF-AHT), P. O. Box 16317, Yaounde, Cameroon.
}

Accepted 12 August, 2011

\begin{abstract}
Emerging literature on agricultural marketing in developing countries recommend some form of partnership/strategic alliances between producers and traders in order to overcome weaknesses of market access orchestrated by a weak institutional environment, prominent of which are poor road infrastructures and inadequate market information systems. Conversely the literature fails to discuss what is necessary to initiate, build and sustain such partnerships. This paper attempts to fill this gap by analysing the case of producer groups and traders in the non-timber forest products (NTFPs) value chains in Cameroon as they attempt to build a sustainable partnership based on trust and commitment. Despite low levels of satisfaction of the outcome of the relationship and low levels of trust between the NTFP producers and traders, they were committed to continue the alliance. We conclude that their commitment to continue the partnership is not related to relationship satisfaction and trusts that were projected to emanate from the respect of mutually agreed upon requirements. Instead, it is based on other strategic reasons like reducing transaction costs that is common in uncoordinated transaction.
\end{abstract}

Key words: Strategic partnership, trust, commitment, producers and traders, non timber forests products, Cameroon.

\section{INTRODUCTION}

A review of 15 years of experiences in NTFP commercialisation, reported by Belcher and Schreckenberg (2007), indicates that commercial approaches used have not universally succeeded in meeting the expectations of local income generation. This calls for more research to complement existing literature that acknowledges the significant contribution NTFPs can make to livelihoods of both producers/collectors and traders in the developing world (Garrity, 2004; Russell and Franzel, 2004; Schreckenberg et al., 2006a). One of such areas of research that has received little attention in the NTFP and other agricultural marketing research literature are studies

*Corresponding author. E-mail: dftita@yahoo.com. Tel: 00237 222150 84. Fax: 22215089. to address means by which farmers and traders can build trust in each other and successfully organise selling and buying arrangements.

In the developed world, buyer-seller relationships and the importance of long-term relationships among buyers and sellers have been extensively studied with regards to supply chain management in the industrial sector (Kaufmann and Carter, 2006; Batt, 2008), as well as in the agribusiness sector (Batt, 2003; Sporleder, 2006; Magistris and Gracia, 2008). Even though quite a good number of studies exist on agricultural associations and cooperatives in developing countries, only a few focused on long-term buyer-seller relationships with attention to smallholder agriculture (Gyau and Spiller, 2007; Bijman, 2008; Masuku, 2009). Yet, it would be wrong to think that such studies are not vital for small farmers and the buyers of their products, especially as it has been proven 
in other supply chains that efforts to develop and sustain buyer-seller relationships may be more productive than conventional marketing investments (Piercy et al., 1997).

The benefits of long-term relationships are that such linkages can create an adequate framework for cooperation and information sharing, mutual learning and provide competitive advantages to partners (Morgan and Hunt, 1994; van der Haar et al., 2001; Magistris and Gracia, 2008; Boniface et al., 2009). When producers enter into a long term relationship with the buyers of their produce, they can benefit from the certainty to sell their products and avoid selling by chance with other advantages being higher incomes and benefits, improved access to inputs, credit and technical assistance (Bijman, 2008). In times of abundance, producers may have to count on such relationships to market their produce and in times of scarcity and stiff competition traders may have to count on these relationships to have access to products they want to buy. Traders' benefits from collaboration with producers, especially when producers are organised in groups, are numerous. When they buy from organised farmer groups that assemble their products at a single spot, they increase their operational efficiency by reducing the transportation and transaction costs that originate from dispersed location of producers. These costs are often very high and lead to the allegation that traders exploit farmers (Dijkstra, 1999; Shepherd 2007). Other advantages traders may experience include improved quality products and improved delivery.

There have been calls in the past (Van der Laan, 1999) and also more recently (Pokhrel and Thapa, 2007; Shepherd 2007) for research and development organisations to overcome the suspicion and neglect of the middlemen in linking farmers to markets and thus promote better partnerships/collaboration between producers and traders in smallholder agriculture. In the NTFP sector in Cameroon and other developing countries, the approach involves improving contacts and sharing of transparent market information between producers and traders (Roshetko et al., 2006; Facheux et al., 2007). Such partnerships developed with the premise to exchange information represent new forms of coordination between producers and traders in the NTFPs sector. Coordination between producer groups and traders can be described as a form of strategic partnering, which is a broader class of governance structure that can be used to illustrate vertical coordination in the supply chain (Sporleder, 2006). These partnerships between producers and traders can be formal or informal (Harrigan, 1988), and in the global food system it may include relational contracts, strategic alliances, working partnerships and ownership integration (Morgan and Hunt, 1994; Sporleder, 2006).

Whatever the form of coordination, it is clear that increasingly producers and traders need to get into some form of partnership/strategic alliances and take advantage of the benefits of long-term relationships mentioned.
This would also help to overcome weaknesses of market access, amongst which bad road networks and poor market and product information. Although the need for improved and sustainable relationships has been reported in the NTFP market literature (Russell and Franzel, 2004; Schreckenberg et al., 2006b) and in agricultural marketing in developing countries in general (Bienabe et al., 2004; World Bank, 2007), the literatures fails to explore how small farmers can initiate, develop and eventually maintain such relationships with the buyers of their produce. This is especially challenging, as scientific literature and mutual perception of producers and traders paint a picture of opportunistic behaviours, a climate of mistrust and conflict that surrounds their buying and selling activities, making it difficult for both parties to cooperate and share transparent market information. Yet, for producers to be effectively linked to markets it does not suffice for the relationship to be created but it has to be preserved, especially when it leads to sustainable positive outcomes.

The main objective of this study is to determine how Cameroonian farmers and traders can initiate and maintain long-term relationships. In order to address this objective, the study intends to answer the following two research questions: (a) What are the main expectations of Cameroonian farmers and traders for entering into business relationships with each other? (b) What are the perceptions of the farmers and the traders concerning their ongoing relationships?

This study attempts to answer these questions within the context of an NGO-assisted strategic partnership building process between producers and traders in the NTFP sector in Cameroon. The analysis is based on data that was collected from njansang and kolanut producers in Cameroon. Analysis focuses on how producers and traders initiated the relationship and came up with mutually agreed terms of collaboration. We also analyse whether the mutually agreed upon terms were respected and how partners perceived the ongoing relationship in terms of trusts, commitment and dependence.

\section{Theoretical framework: Determinants of sustainable buyer-seller relationship}

This study is based on the theory of relationship marketing (Anderson and Weitz, 1989; Morgan and Hunt, 1994; Batt, 2003; Kwon and Suh, 2004; Maheshwari et al., 2004), according to which some prerequisites are necessary for potential partners to initiate, develop and maintain a sustainable partnership. These prerequisites include, amongst others: establishment of mutually agreed upon norms of conduct, mutual trust, commitment, interdependency, flexibility and two-way information sharing. These preconditions have been situated in a five stage evolutionary process as follows ( $\mathrm{Ng}, 2008)$ : 


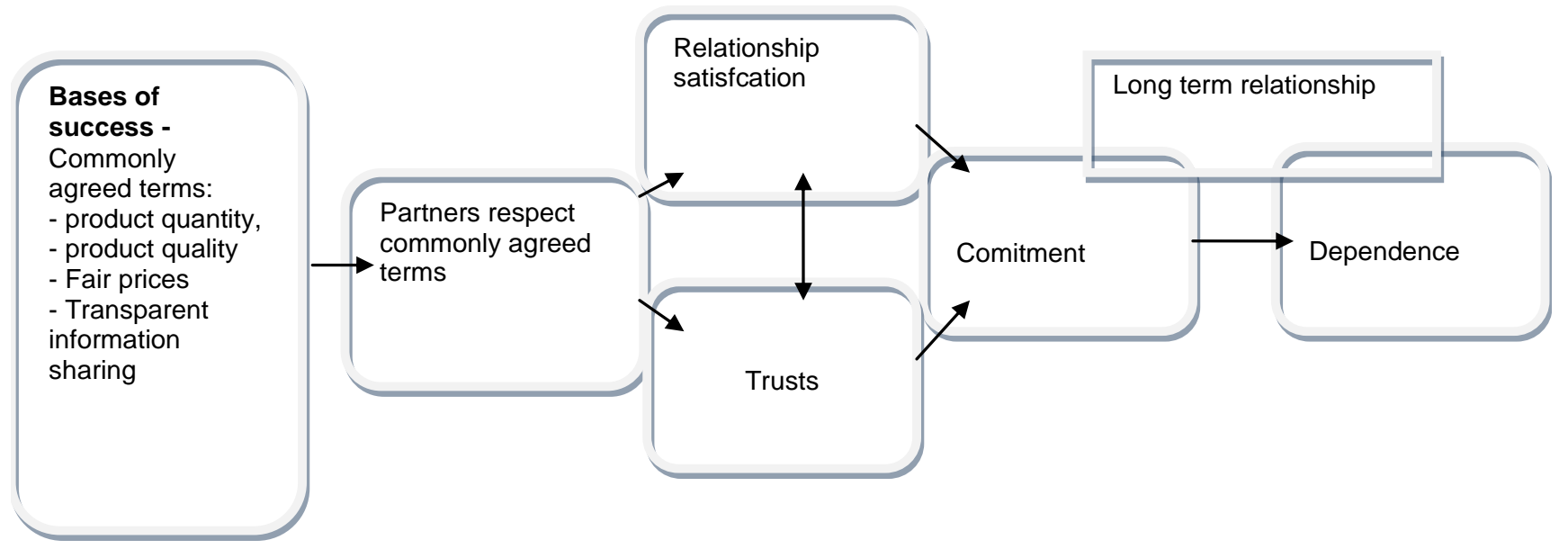

Figure 1. Conceptual framework.

Stage one is the pre-relationship phase and involves evaluation of new potential partners in order to determine if the relationship is feasible. Stage two is the early stage during which both parties seek and exchange information on one another through direct contacts. In this way the potential and risk of the relationship are evaluated. Stage three is the development phase during which both parties commit to the course and make necessary investments to ensure continuity. Communication and trust continue to grow at this stage leading to increased cooperation. The fourth stage is the long term during which both parties carry on routine exchanges based on mutual trust and commitment. At the final stage, partners tend to minimise uncertainty and apply sanctions such as termination based on dissatisfaction. However, when partners perceive high termination cost it increases their desire to maintain a relationship leading to dependence (Heide and John, 1988).

Our conceptual argument (as illustrated in Figure 1) is that, for producers and traders in the NTFPs value chain in Cameroon to establish a sustainable partnership, they need to agree on some basic norms of collaboration. These may include: product quantity, quality, fair prices and transparent sharing of market information. We postulate that for the relationship to be successful, partners must respect the mutually agreed upon standards/norms. Respect of the terms of the partnership will lead to satisfaction and trust between partners. Trust and satisfaction are expected to increase partners' desire to maintain the relationship (commitment). Since partners' benefits are comparatively higher than would exist in uncoordinated transactions, dependence of one group of actors on another would lead to a situation where partners would not want to terminate the partnership.

In this study, we operationtionalise the definitions of our conceptual framework. We describe the concepts of trust, commitment and dependency as we argue that they are instrumental in sustaining the relationship between NTFPs producers-traders in Cameroon.

\section{Trust}

Trust exists when one party has confidence in an exchange partner's reliability and integrity which are associated with qualities like consistent, competent, honest, fair, responsible, helpful and benevolent (Morgan and Hunt, 1994). Limited trust will lead to low performance of the partnership and thus negatively affects its sustainability (Jobin, 2008). In this research, trust takes into consideration elements such as honesty and benevolence as used by Kumar et al. (1995). Trust in partners' honesty is the belief that partners stand by their words, fulfil promised roles and are sincere. On the other hand, benevolence is the belief that the partner is interested in the firm's welfare and will not take unexpected actions that will negatively affect the partnership (Kumar et al., 1995; Claro and Omta, 2005).

Producers' and traders' honesty in this study took into consideration the extent to which both parties are honest, truthful and reliable with regard to certain transaction characteristics which were identified as necessary for maintaining the relationship. These include information sharing, and respect of pre-agreed quantity and quality. Their benevolence was measured to capture the belief that both consider the welfare of each other. For example, partners would not cheat and would endeavour to offer fair prices that reflect the real market conditions.

\section{Commitment}

Like trust, commitment to a relationship emerges from 
economic and behavioural components (Maheshwari et al., 2004). According to Anderson and Weitz (1992) commitment requires the willingness of partners to make short term sacrifices to grasp long term gains (Dwyer et al., 1987). Mutual commitment results in partners working together to increase mutual benefits (Ganesan, 1994). In literature, a difference is made between affective and cognitive-calculative commitment (Sharma et al., 2001). Affective commitment represents emotional attachments and the extent to which partners are motivated to continue a relationship due to their liking for it. On the other hand, cognitive-calculative commitment emanates from economic calculations. Calculative commitment may be negative or positive (Sharma et al., 2001). Negative commitment refers to the situation where partners experience the need to maintain a relationship due to the high cost that may result from terminating it (Heide and John, 1988; Sharma et al., 2001) while positive commitment refers to the need to continue a relationship based on positive previous experience or increased benefits and reduced costs (Morgan and Hunt, 1994; Sharma et al., 2001).

In this study, to measure commitment, producers and traders answered questions related to their desire to continue trading with the same partners even if others exist due to the positive effect of the relationship on them.

\section{Dependency}

Besides trust and commitment, other studies have investigated the importance of perceived dependence in long term buyer-seller relationships (Ganesan, 1994; Heide, 1994; Narasimhan et al., 2009). The dependence of a seller (producer) on a buyer (trader) in a supply chain relationship refers to the seller's (producer's) need to maintain the relationship to achieve the desired goals (Frazier, 1983). Heide and John (1988) note that the dependence of one actor on another increases when the outcomes obtained from a relationship are important or highly valued. This may be in relation to the magnitude of the transaction or when the outcomes of the relationship are comparatively higher than available alternative sources or when fewer alternative sources of exchange exist. In this study, dependency took into consideration the perception of the importance given by traders and producers to the continuity of collaboration, the availability of alternative buyers for producers and alternative producer groups for traders, and the ease of replacing a partner and establishing trust with a new partner.

\section{METHODOLOGY}

\section{Target population and type of data}

In Cameroon, as part of a strategy to link NTFP producers to markets, members of two producer groups: Twantoh Mixed Farming
Common Initiative Group (MIFACIG) and Association pour le Développement Intégral des Exploitants Agricoles du Centre (ADEAC), had formed marketing subgroups specialised in selling two NTFPs: Cola anomala (kola nuts) and Ricinodendron heudelotii (njansang) respectively. MIFACIG and ADEAC were chosen as pilot groups for the execution of the Farmer Enterprise Development project (FED) headed by the World agroforestry Centre (ICRAF). The objective of the FED project was to increase market opportunities for farmers through improved market skills and strategies. The choice of the two farmer groups by the FED project was backed by the abundance of the two selected species in the study area and the desire of its members to market the selected products as a group.

These marketing groups were linked to traders in urban markets through a series of consultation meetings organised within the FED project. The objective of these meetings was for both trading parties (producers and traders) to develop guidelines for establishing a sustainable buying and selling partnership. The targeted farmers in this study were members of kola and njansang marketing sub groups within MIFACIG and ADEAC distributed over six different villages in the North West and Centre Regions of Cameroon. The traders were members of a network of traders in urban markets dealing with kola nuts and njansang and had been involved in a business relationship with MIFACIG and ADEAC farmers.

\section{Data collection}

The information reported in this study was collected in two phases. The first phase consisted of focus group meetings that were organised before the start of group sales between the selected NTFPs producers and the traders. The second phase was a survey using a structured questionnaire administered to producers and traders five years after the partnership was established. In the first phase (focus group), information was collected from producers and traders on what they thought were necessary to build a strategic partnership between them so that the producer groups could supply required quality and quantity to the traders. The focus group discussions were held in July 2004.

Producers that attended the focus group were: the head of each marketing sub group, officers in charge of marketing and an animator from each participating subgroup. Traders who took part in the focus group were wholesalers identified by ICRAF and Centre for International Forestry Research (CIFOR) during a survey preceding this meeting aimed at analyzing the marketing chain of the kola sub sector. They were chosen based on the criteria that: (a) they must be dealing with either kola or njansang, (b) must be a wholesaler or large scale wholesaler-retailer, (c) have enough capital to buy large quantities mobilised by farmer groups, and (d) were willing to participate in the project. In all, 12 farmers (six kola nuts and six njansang producers) and 15 traders (eight kola nuts and seven njansang traders) took part in the focus group discussions. Njansang and kola nuts farmers were in separate groups, as were kola nuts and njansang traders. The groups were guided in their discussions by ICRAF and CIFOR scientists.

Since farmers and traders had to work separately in two teams and for each product, at the end of the brain storming in the four separate groups, members presented their findings to others and points of disagreements and common interests were noted and debated upon. The main outcome of the focus group discussions were grouped by participants into expectations, main fears and prerequisites for collaboration. The main questions both categories of actors had to discuss in the focus groups were: (a) what sort of information is required for producers and traders to get into an effective/efficient and sustainable partnership? (b) What are the prerequisites of success?

In the second phase of data collection, a structured and tested questionnaire was used to evaluate the existing relationship five 
years after it was contracted. In this case, the objective was to analyse producers' and traders' perception of the sustainability of the on-going partnership and their perceived trust, commitment and dependence as prerequisites to the sustainability of the on-going relationship. The sampling frame was made up of 223 farmers and 37 traders who had been involved in buyer-seller relationships since March 2003. A sample of 54 farmers and 17 traders representing 24 and $48 \%$ of the target population size, respectively, were randomly selected from the sampling frame for interview. In answering the questions, both producers and traders were asked to focus on a single buyer or a group of buyers with whom they had had strategic alliances since 2003 within the framework of the FED project that initiated the process. Data were collected from April to mid May 2009.

\section{The questionnaires}

The questionnaires contained questions on household characteristics, and on their economic activities. The measurement of levels of trust, commitment and dependency were assessed using a five point Likert scale. The Likert items had numerical choices ranging from $1=$ strongly disagree to $5=$ strongly agree. The midpoint of this scale was 3 and all scores above 3 were considered to be in agreement with the item and those below three were considered to be in disagreement with the item. Scores equal to three were considered as neutral in opinion to the item. Analyses focused on descriptive statistics of the percentage of farmers that agreed or disagreed with the Likert scale items. Higher percentage scores in agreement for an item, for example producers' trust in traders, would mean a majority of the producers trust the traders based on that item being measured. A Man Whitney $U$ test was used to compare if the opinion of farmers or traders differed significantly from each other for each of the items used. The Mann Whitney $U$ test checks the null hypothesis that both producers and traders have on average the same ranking of the Likert items. The analysis was done in SPSS version 16.

\section{RESULTS AND DISCUSSION}

\section{Main findings from focus group discussions}

\section{Mutual expectations of producers and traders to initiate a partnership}

As postulated in the conceptual framework, producers and traders agreed on the desired product quantity and quality while initiating the partnership. Besides adequate quantity and quality of products demanded by traders, they requested that supplies should be regular and timely. Producers were requested to improve on their communication with traders by calling them regularly to inform them of production and supply conditions.

The issue of communication was also important for the producers. Producers' expectations were principally centred on the need for traders to adequately inform them of what quantity and quality of produce they need for effective collaboration and at what time they would need what quantity. They requested the traders (especially kola nut traders) to share their experience on storage techniques with them so that they could be able to store the products and supply when the traders need them. They also expressed the need for traders to open up as regards their destination markets and the type of quality needed for specific markets so they can process accordingly.

\section{Sources of mistrust}

It stems from the group discussions that traders doubted the production capacity of the producers, to supply enough quantities to break even their marketing costs when they travel to production villages. Producers on their part doubted the purchasing power of traders and wondered if they had enough capital to buy huge quantities the groups were going to mobilise. Both producers and traders accepted that even if the main doubts are erased and their expectation met, the partnership will not work if partners do not meet up with the following conditions: (a) mutual respect for each other; (b) transparent marketing practices void of unethical techniques common in un-coordinated market deals. For example, kola nut farmers were quoted of 'filling half their baskets with weevil infested kola nuts', whereas njansang farmers were accused of 'mixing intact and broken kernels'. Another common unethical practice by farmers involved harvesting immature kola nuts when demand increased which easily dries up to a state not suitable for the market. Such attitudes leave the traders at a loss. Traders were warned by producers to stop using false measuring units. Based on this information it can be said that, while traders did not trust the production capacity of producers, the latter doubted the purchasing power of the traders. Both producers and traders did not trust each other as concerns cheating techniques that may be used by one on another.

To collaborate with farmer groups, traders examined their own behaviour and insisted that it would be necessary to organise themselves to meet the challenges of buying large volumes mobilised by producer groups. They also emphasized the need to circulate transparent information about quantities available in other supply villages and to be honest with regards to information given to producers.

The weaknesses identified were addressed in subsequent meetings by producers and traders before they went into business. For example, traders decided to organise themselves to mobilise enough capital to buy from the groups. Producers decided to improve their coordination and quality verification mechanism in order to supply the required quantity and quality.

\section{Evaluation of on-going partnerships}

\section{Relationship satisfaction}

Survey results indicate that a majority of both producers 


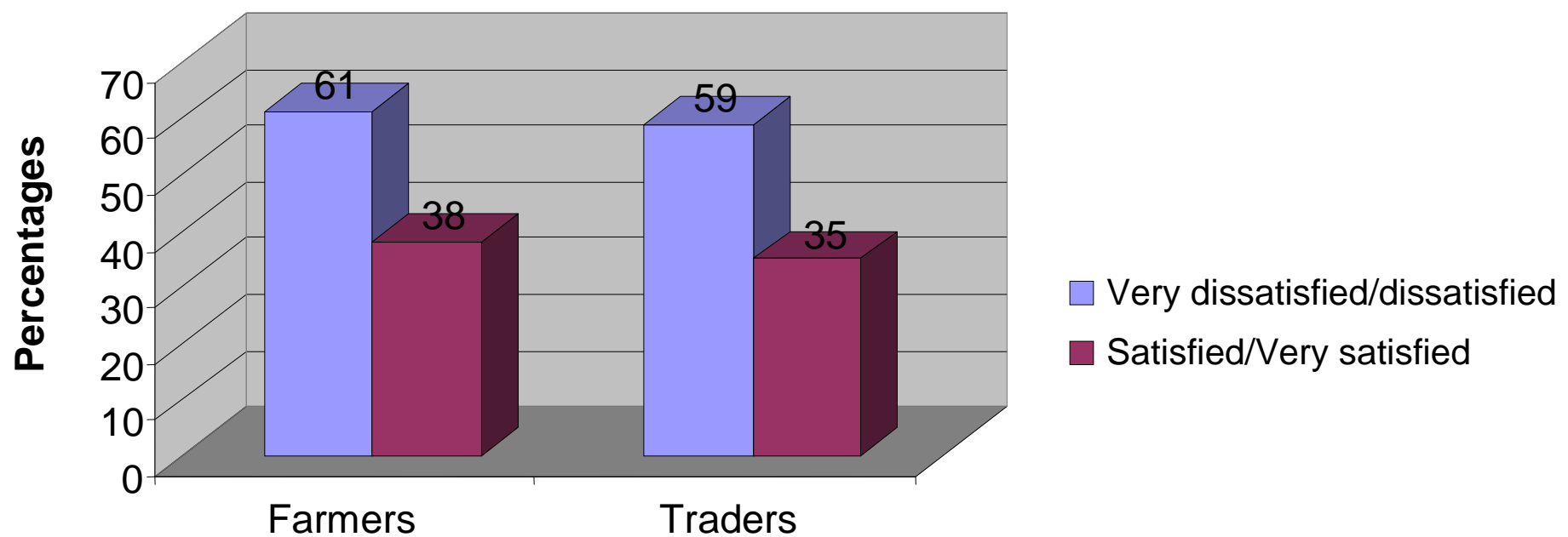

Farmers/traders

Figure 2. Producers/traders satisfaction with relationship sustainability.

$(61 \%)$ and traders (59\%) were either dissatisfied or very dissatisfied with the relationship five years after they engaged in the partnership, and thought it would not last long (Figure 2). The question arises as to what may be the causes of this fear? To answer this question reference is made to our conceptual framework where we insist that partners must set up bases for collaboration and respect them in order to instil a climate of trust and commitment necessary to sustain trade relationships.

\section{Trust between producers and traders}

The principal issue investigated in this section is whether producers and traders had developed trust in each other with regard to the initially agreed upon terms of collaboration. Analyses show that after five years of collaboration, a majority of both producers and traders do not trust each other with respect to the quality of information shared on produce quantities and quality (Table 1). For example, $77 \%$ of producers do not trust the quality of information traders give with regard to prices prevailing in urban markets. Also, a majority of traders $(63 \%)$ do not trust producers when it comes to information about their potential to supply the desired quantity and quality.

Results show that while a majority of producers (63\%) trust traders' purchasing power, only a small proportion of traders trust producers' capacity to supply required volumes. Producers obtained a significant higher mean rank score 37.6 against 26.9 for this item indicating that more farmers trust traders' purchasing power as compared to a lower number of traders who think that producers can supply requested volumes. This high negative perception may eventually force a majority of the participating traders to withdraw from trade with the farmers, leading to a break in the partnership. Especially as it stemmed from traders' opinion in the focus groups discussions that they need to mobilise capital as a group to buy from organised farmer groups.

More than half of the respondents $(57 \%$ producers and $63 \%$ traders) think the other party will cheat if they have the opportunity of doing so. This reflects elements of severe mistrust on the trading practices of a majority of producers and traders in the exchange relationship, and may lead to unsuccessful market transactions as both groups will have to develop strategies to make sure the other party does not cheat. Such defence mechanisms lead to high transaction costs which have negative consequences on the relationship outcomes.

Group market transactions between the interviewed producers and traders in the NTFPs sector are often characterised by high uncertainty about prices and quantities. This requires that partners in the relationship are flexible to initially agree upon terms. Rise and fall of market prices may force producers and traders to always come back to renegotiate initially agreed upon market conditions; the consequence of which may be increased transaction costs and a reduction in trust between both parties.

Analyses of the item used to measure flexibility indicate mutual flexibility of a majority of both producers and traders (53 and $75 \%$ respectively) but significant differences were observed in their mean rank responses. Traders obtained a higher mean rank 44 against 32 for producers, suggesting higher levels of confidence that producers will change initially agreed upon terms (for example, when prices drop in urban markets). The lower mean rank scored by producers reflects high levels of disagreement with the item and is an indication that 
Table 1. Producers' and traders' perception of different trust items ${ }^{a}$.

\begin{tabular}{|c|c|c|c|c|c|c|c|}
\hline & \multirow{2}{*}{\multicolumn{2}{|c|}{$\begin{array}{c}\text { Distrusts } \\
\begin{array}{c}\text { Strongly disagree/ } \\
\text { disagree }\end{array}\end{array}$}} & \multicolumn{2}{|c|}{ Trusts } & \multirow{3}{*}{$\begin{array}{c}\text { Mean ranks } \\
\text { Farmers } \mathrm{N}= \\
54\end{array}$} & \multirow{3}{*}{$\begin{array}{c}\text { Mean ranks } \\
\text { Traders N = } \\
17\end{array}$} & \multirow{3}{*}{$\begin{array}{c}\text { Mann } \\
\text { Whitney U } \\
\text { Z-value/P- } \\
\text { value }\end{array}$} \\
\hline & & & \multicolumn{2}{|c|}{ Agree/strongly agree } & & & \\
\hline & Farmers & Traders & Farmers & Traders & & & \\
\hline $\begin{array}{l}\text { Trust in information: on } \\
\text { quantities/ prices given by } \\
\text { producers /traders }\end{array}$ & $41(77)$ & $10(63)$ & $9(17)$ & $3(19)$ & 33.49 & 40.00 & $-1.20 / 0.22$ \\
\hline $\begin{array}{l}\text { Trust in information about } \\
\text { quality often true }\end{array}$ & $39(74)$ & $7(44)$ & $12(23)$ & $7(44)$ & 35.6 & 33.00 & $-0.48 / 0.63$ \\
\hline $\begin{array}{l}\text { Trust the reliability of traders } \\
\text { /producers in terms of } \\
\text { enough capital and } \\
\text { producers enough quantity }\end{array}$ & $18(34)$ & $8(50)$ & $33(63)$ & $5(31)$ & 37.66 & 26.19 & $-2.09 / 0.03^{\star *}$ \\
\hline $\begin{array}{l}\text { Benevolence (cheating): } \\
\text { Producers and traders will } \\
\text { act and negotiate fairly even } \\
\text { if the possibility of cheating } \\
\text { exist }\end{array}$ & $30(57)$ & $10(63)$ & $23(43)$ & $5(31)$ & 36.49 & 30.06 & $-1.17 / 0.24$ \\
\hline $\begin{array}{l}\text { Flexibility:producers/traders } \\
\text { are flexible to change order } \\
\text { (prices and quantities) }\end{array}$ & $23(43)$ & $3(19)$ & $28(53)$ & $12(75)$ & 32.40 & 43.62 & $-2.11 / 0.03^{* *}$ \\
\hline
\end{tabular}

${ }^{a}$ Likert items: 1 to 5 strongly disagree-/strongly agree. Higher scores reflect high trust; responses reflecting neutral scores are not represented in the table; percentage of respondents are in parenthesis; Mann Whitney U test: significant at $1 \%={ }^{* * *}$ significant at $5 \%={ }^{* *}$ significant at $10 \%={ }^{*}$.

Table 2. Summary table of trust items.

\begin{tabular}{lccc}
\hline Elements of trusts & $\begin{array}{c}\text { Majority of producers trust } \\
\text { traders on this item? }\end{array}$ & $\begin{array}{c}\text { Majority of traders trusts } \\
\text { producers on this item }\end{array}$ & $\begin{array}{c}\text { Existence of } \\
\text { mutual trusts }\end{array}$ \\
\hline Honesty information on quantity & No & No & No \\
Honesty information on quality & No & No & No \\
Reliability & Yes & No & No \\
Benevolence & No & No & No \\
Flexibility & Yes & Yes & Yes \\
Total number of yes & $2 / 5$ & $1 / 5$ & $1 / 5$ \\
\hline
\end{tabular}

producers have less confidence that traders will change initially agreed buying terms when market conditions improve for the better. This interpretation follows producers' narrative comments during data collection that traders often use fluctuating prices in urban markets to bargain for lower buying price, which according to the producers may not be true. This means that ignorant of reliable information on market prices, producers' are forced to operate as price takers.

In summary for all the five items used to measure trust, a majority of the producers interviewed do not trust traders on three out of the five items, while traders do not trust producers on four out of the five items (Table 2).
Mutual trusts exist for one out of the five items. This means that, despite precautions taken at the beginning of the relationship, partners have not been able to build trust amongst them and may account for the low levels of partnership satisfaction.

\section{Commitment to long term relationships with existing partners}

For all the three items used in measuring commitment, a majority of both farmers and traders indicated their desire to continue trading with each other (Table 3 ). $74 \%$ of 
Table 3. Producers' and traders' commitment to long term relationship ${ }^{a}$

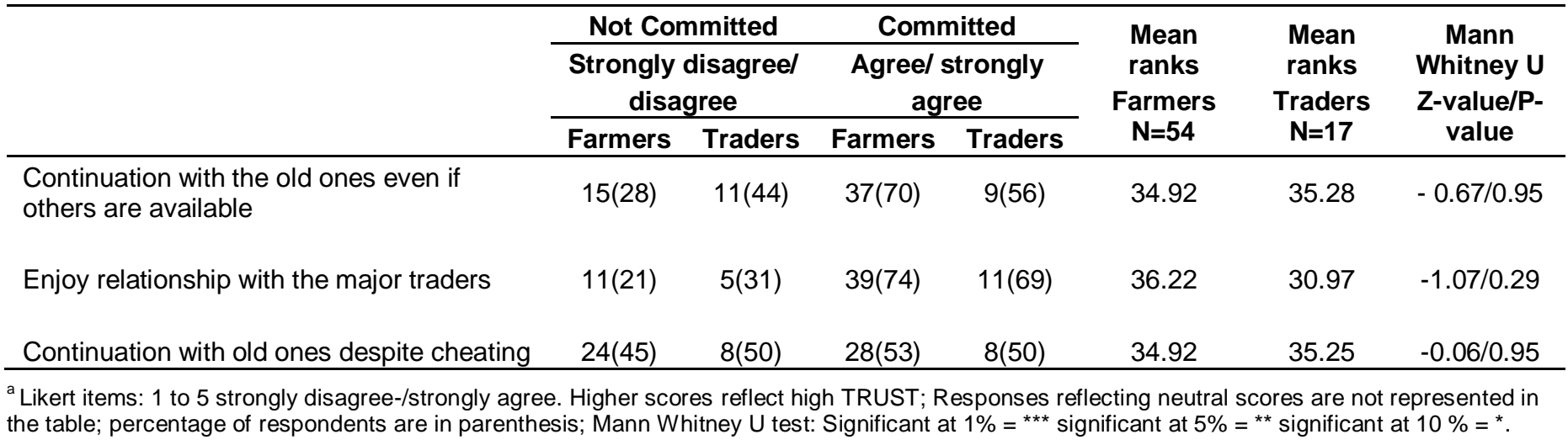

Table 4. Producers' and traders' perception of dependency ${ }^{a}$

\begin{tabular}{|c|c|c|c|c|c|c|c|}
\hline & \multicolumn{2}{|c|}{$\begin{array}{c}\text { Not Dependent } \\
\begin{array}{c}\text { Strongly disagree/ } \\
\text { disagree }\end{array} \\
\end{array}$} & \multicolumn{2}{|c|}{$\begin{array}{c}\text { Dependent } \\
\begin{array}{c}\text { Agree/ strongly } \\
\text { agree }\end{array} \\
\end{array}$} & \multirow{2}{*}{$\begin{array}{c}\text { Mean } \\
\text { ranks } \\
\text { Farmers } \\
\mathrm{N}=54\end{array}$} & \multirow{2}{*}{$\begin{array}{c}\text { Mean } \\
\text { ranks } \\
\text { Traders } \\
\mathrm{N}=17\end{array}$} & \multirow[t]{2}{*}{$\begin{array}{c}\text { Mann Whitney } \\
\text { U Z-value/ P- } \\
\text { value }\end{array}$} \\
\hline & Farmers & Traders & Farmers & Traders & & & \\
\hline $\begin{array}{l}\text { This trader/producer group is important } \\
\text { for future sales }\end{array}$ & 18(34) & $3(19)$ & $33(62)$ & 13(82) & 32.08 & 44.69 & $-2.384 / 0.017^{\star *}$ \\
\hline $\begin{array}{l}\text { The trader/producer group cannot } \\
\text { survive without our producer/trader group }\end{array}$ & $8(15)$ & $7(44)$ & $43(81)$ & $8(50)$ & 37.07 & 28.16 & $-1.69 / 0.09$ \\
\hline $\begin{array}{l}\text { It is difficult to find: new buyers with large } \\
\text { capital /an organised producer group }\end{array}$ & $16(30)$ & $2(13)$ & $37(70)$ & 14(88) & 33.60 & 39.62 & $-1.15 / 0.25$ \\
\hline $\begin{array}{l}\text { It is difficult to establish trust with new } \\
\text { buyers }\end{array}$ & $9(17)$ & $6(35)$ & $42(79)$ & $11(65)$ & 37.76 & 28.44 & $1.76 / 0.08^{*}$ \\
\hline
\end{tabular}

${ }^{a}$ Likert items: 1 to 5 strongly disagree-/strongly agree. Higher scores reflect high trust; Responses reflecting neutral scores are not represented in the table; percentage of respondents are in parenthesis; Mann Whitney $U$ test: significant at $1 \%={ }^{* \star *}$ significant at $5 \%={ }^{* \star}$ significant at $10 \%={ }^{*}$.

the producers and $69 \%$ of the traders indicated they will continue the relationship even if alternatives are available because they enjoyed the partnership. This may sound strange after a majority had expressed dissatisfaction and fear that the relationship would not last long. This discrepancy can be explained by the fact that both groups of actors are aware of the high transaction costs that may be involved in switching to a new partner so they prefer to remain with the ones they are used to. Moreover, almost $50 \%$ of both producers and traders would continue the relationship even if the other partner cheats. This is a further reflection of their commitment to the partnership and confirms the findings by Ganesan (1994) that members are ready to make short term sacrifices hoping that they can improve on this as they continue to know each other.

Since traders are known to have multiple sources of supply compared to producers having few alternative buyers to whom they can sell, it was hypothesised that producers will be more committed to establishing longterm relationships than traders. The Mann Whitney $U$ test comparing, producers' and traders' commitment to one another shows no significant differences indicating mutual commitments by a majority of producers and traders to maintain the partnership.

\section{Dependency on one another}

Four items were used to assess dependency of one group of actors on another. Results suggest that both groups perceive each other to be important to the survival of their business. However, the Mann Whitney $U$ test reveals that there were significant differences in perception between producers and traders for three of the items measuring dependency (Table 4). For example, although both traders and producers think their partners in the relationship are important for subsequent sales, 
traders had a higher mean rank (44.69 against 32.08 ) on this item suggesting a stronger desire to collaborate with producer groups. In the same line of thinking, a significantly higher majority of producers $(80 \%)$ thinks that traders cannot survive in the business without them (mean rank 37 against 27), while a comparatively lower percentage of traders $(41 \%)$ are of the opinion that the particular producer group are not important to the survival of their business.

While a majority of interviewed producers (69\%) and traders $(82 \%)$ think it is difficult to replace existing partners, traders had a higher mean rank 39.60, an indication of a stronger agreement about the difficulty in replacing the partner producer group and thus stronger dependency on the part of traders on the producer group. This strong dependency can be explained by the fact that traders bear most of the marketing costs when they move around buying from door to door, whereas when they buy from an organised group, they reduce marketing and transaction costs. According to Heide (1994), the absence of symmetric dependence between parties in a relationship reduces the incentives for partners to show flexibility as a means of preserving a relationship, as no guarantee exists that such an action will be reciprocated. This may explain the high rate of relationship un-sustainability expressed by both parties.

\section{Conclusions}

Conceivably, the salient conclusions that can be drawn from the expectations of producers on traders and vice versa based on the focus group discussion are that product quantity, quality, prices and good ethical practices are important factors necessary to start, build and maintain sustainable producers-trader partnerships in the NTFPs sector in Cameroon. Further, associates to the partnership would need both parties to respect mutually-agreed upon arrangements, exhibit honest practices and be reliable. These attributes should be negotiated at the time the relationship is initiated. In addition to these, and perhaps specific to less developed countries, are factors related to having reliable market information. This may be outside the control of producers and traders, since each may want to take advantage over the other. A reliable public market information system supported by the state or NGOs may complement the system put in place by farmers in a partnership.

Even though it may be easy to set guiding blocks to relationship sustainability at the initiation phase, this study shows that it is difficult for producers and traders to respect mutually agreed upon terms of collaboration because of general mistrust they have of each other. This makes it difficult for both parties to build and develop strategic trust based on the initially defined guiding blocks. In the absence of mutual trust, exchange will not take place to the detriment of the actors involved and the society at large (Knack and Keefer, 1997). The study shows that levels of mistrust were highest on the item measuring quality of information shared; indicating that if both parties (but especially producers) are aware of existing market information it will reduce opportunistic behaviours. In addition, if both parties use more transparent measuring units, then the level of trust in their trading practices will increase leading to more successful and sustainable partnerships.

This feeling of mistrust may account for the negative perception producers and traders have of each other concerning the sustainability of the partnership. However, despite low levels of trust and satisfaction manifested by producers and traders in the partnership, the study shows that both parties are committed to continue trading with each other. This type of commitment can be likened to negative calculative commitment or locked-in commitment hitherto described (Sharma et al., 2001) which may result from the high perceived costs of switching to new partners. In this case, the high switching costs may be explained by the difficulties producers and traders go through to market their produce in the absence of the existing strategic partners. Morgan and Hunt (1994) refer to such difficulties as termination costs which they describe as 'all expected benefits from termination that result from perceived lack of comparable alternative partners'. Heide and John (1988) refer to this as switching costs or the costs of replaceability and argue that it may lead to dependence. We abide to this view by referring to one of the elements used to measure dependency which shows that more than $70 \%$ of producers and $88 \%$ of traders in the partnership think it is difficult to replace existing partners.

This study did not reveal which of these factors (respect of mutual agreements or circulation of transparent information) may be more important in building trust between producers and traders in the NTFP sector in Cameroon. But we argue that elements of the study such as bases of success defined in the focus group discussions can be used to advise producers and traders of what one group of actors expects of the other. Such information can be useful in developing sustainable buyer-seller relationships especially within the context of group marketing and contract farming that are gradually taking root in smallholder agriculture in developing countries.

\section{ACKNOWLEDGEMENTS}

The authors would like to thank the Belgian Development Cooperation (DGDC) for providing the necessary funds to carry on this study within the Farmer Enterprise Development (FED) project and the Agroforestry Tree Products for Africa (AFT4A). We appreciate the comments and inputs from anonymous reviewers. We would also like to thank our partners with whom we 
collaborated in the FED and (AFT4A) projects.

\section{REFERENCES}

Anderson E, Weitz B (1989). Determinants of Continuity in Conventional Industrial Channel Dyads. Market. Sci., 8: 310-323.

Anderson E,Weitz B (1992). The Use of Pledges to Build and Sustain Commitment in Distribution Channels. J. Market. Res., 29: 18-34.

Batt PJ (2003) Building Trust between growers and market agents. Supply Chain Manage. Int. J., 8: 65-78.

Batt PJ (2008). Building Social Capital in Networks. Ind. Market. Manage., 37: 487- 491.

Belcher B, Schreckenberg K (2007). Commercialisation of Non Timber Forests Products. A Reality Check Development Policy Review, 25: 357-377.

Bienabe E, Coronel C, Le Coq J-F, Liagre L (2004). Linking Small holder farmers to markets: Lessons learned from Literature and analytical review of selected projects. In Study report: World Bank.

Bijman J (2008). Contract Farming in Developing Countries: an Overview. In Working paper Wageningen Wageningen University, Department of Business Administration.

Boniface B, Gyau A,Stringer R (2009). Relatioship quality as the predictor of long term relationships in the Malaysian diary Industry In 4th International Asian accademy of applied business conference Manilila-Philippines.

Claro DP, Omta O (2005). Building Collaborative Relationships with Distributors in the Dutch Potted Flower and Plant. J. Int. Food Agribus. Market., 17: 15-38.

Dijkstra T (1999). Horticultural Marketing in Kenya: Why Potatoes Farmers need Collecting Wholesalers In Agricultural Marketing in Tropical Africa: Contributions from the Netherlands [LH van der Laan, $\mathrm{T}$ Dijkstra and A van Tilburg, editors]. Leiden: African studies Research Centre, Leiden.

Dwyer FR, Schurr PH, Oh S (1987). Developing Buyer-Seller Relationships. J. Market., 51: 11-27.

Facheux C, Tchoundjeu Z, Foundjem-Tita D, Degrande A, Mbosso C (2007). Optimising the production and marketing of NTFPs. Afr. Crop Sci. Proc., 8: 1249-1254.

Frazier GL (1983). Determinants of Long Term Orientation in Buyer Seller Relationships. J. Market., 20: 158-166.

Ganesan S (1994). Determinanants in Buyer Seller Relationships J. Market., 58: 1-19.

Garrity DP (2004). Agroforestry and Achievement of the Millennium Development Goals. Agrofor. Syst., 61: 5-17.

Gyau A, Spiller A (2007). The role of organizational culture in modeling buyer-seller relationships in the fresh fruit and vegetable trade beween Ghana and Europe. Afr. J. Bus. Manage., 1: 218-229.

Harrigan KR (1988). Joint Ventures and Competitive Strategy. Strateg. Manage. J., 9: 141-158.

Heide JB (1994). Interorganizational Governance in marketing Channels. J. Market., 58: 71-85.

Heide JB, John G (1988). The Role of Dependence Balancing in Safeguarding Transaction-Specific Assets in Conventional Channels. J. Market., 52: 20-35.

Jobin D (2008). A Transaction Cost-Based Approach to Partnership Performance Evaluation. Evaluation, 14: 437-465.

Kaufmann L, Carter CR (2006). International supply relationships and non financial performance - A comparison of US and German practices. J. Oper. Manage., 24: 653-675.

Knack S, Keefer P (1997). Does social capital have an economic pay off ?: A cross country investigation Quarterly J. Econ., pp. 1251-1288.

Kumar N, Scheer LK, Steenkamp J-BEM (1995). The Effects of Perceived Interdependence on Dealer Attitudes. J. Market. Res., 32: 348-356.

Kwon I-WG, Suh T (2004) Factors Affceting the Level of Trust and Commitment in Supply Chain Relationships. J. Supply Chain Manage., pp. 4-14.
Magistris T, Gracia A (2008). Co-Operation and Economic Relationship as Determinants for Competiveness in the Food Sector: The Spanish Wheat to Bread Chain. In 12th Congress for the Association of Agricultural Economics- EAAE. Ghent.

Maheshwari B, Kumar V,Kumar U (2004). Managing Supply Chain Partnerships: A Framework for Optimal Success. In ASAC 2004 Conference. Quebec city.

Masuku MB (2009). The Role of Trust in Contract Enforcement: An Analysis of small holder farmers and Sugar Millers in Swaziland. In Institutional Economic perspective on African agricultural Development [JF Kirsten, AR Doward, C Poulton and N Vink, editors]. Washington D.C.: International Food Policy resource Institute.

Morgan RM, Hunt SD (1994). The Commitment - Trust Theory of Relationship Marketing. J. Market., 58: 20-30.

Narasimhan R, Nair A, Griffith DA, Arlbjorn SJ,Bendoly E (2009). Lock in situations in supply chain: A social exchange theoretic study of sourcing arrangements in buyer-supplier relationships Journal of Operations Management in press.

$\mathrm{Ng} \mathrm{E}$ (2008). A dyad perspective of buyer-seller relationships - the case of Taiwan agribusinesses. In Australian and New Zealand Marketing Academy (ANZMAC) Conference 2008: Shifting Focus from the Mainstream to Offbeat [D Spanjaard, S Denize and N Sharma, editors]. Sydney, Australia: Australian and New Zealand Marketing Academy (ANZMAC).

Piercy NF, Katsikeas CS, Cravens DW (1997). Examining the Role of Buyer Seller Relationships in Export Performance. J. World Bus., 32: 74-86.

Pokhrel DM, Thapa GB (2007) Are Marketing intermediaries exploiting mountain farmers in Nepal? A study based on market price, marketing margin and income distribution analyses. Agric. Syst., 94: 151-164.

Roshetko JM, Nugraha E, Tukan JCM, Manurung G, Fay C,Van Noordwijk M ( 2006). Agroforestry for livelihood enhancement and enterprise development. Proceedings of the international workshop for integrated rural development In East Nusa Tengara.

Russell D, Franzel S (2004). Trees of prosperity: Agroforestry, Markets and the African Smallholder. Agrofor. Syst., 61: 345-355.

Schreckenberg K, Awono A, Degrande A, Mbosso C, Ndoye O, Tchoundjeu Z (2006a). Domesticating Indigenous fruit trees as a Contribution to poverty reduction Forests trees and Livelihoods 16

35-51.

Schreckenberg K, Marshall E, Newton A, Te Velde DW, Rushton J, Edouard F (2006b). Commercialisation of Non-Timber Forests Products: What determines success . ODi Forestry Briefing. In ODi Forestry Briefing.

Sharma N, Young L, Wilkinson I (2001). The structure of relationship commitment in interfirm relationships In IMP Conference Oslo, Norway.

Shepherd AW (2007). Approaches to Linking Producers to Markets. A review of experiences to date. In Agricultural Managemnet, Marketing and Finance Service . Occasional paper. Rome: FAO.

Sporleder TL (2006). Strategic Alliances and Networks in Supply Chains. In Quantifying the Agri-food Supply Chain, pp. 161-171: Springer.

van der Haar J, Kemp RGM, Omta O (2001). Creating Value that cannot be copied. Ind. Market. Manage., 30, 627- 636.

Van der Laan LH (1999). Agricultural Marketing in Tropical Africa: Obstacles to Systematic study. In Agricultural Marketing in Tropical Africa: Contributions from the Netherlands [ $\mathrm{LH}$ Van der Laan, T Dijkstra and Av Tilburg, editors]. Leiden, Netherlands: Ashgate Publishing Limited.

World Bank (2007). Agriculture for Development Washington D. C. : World Bank. 